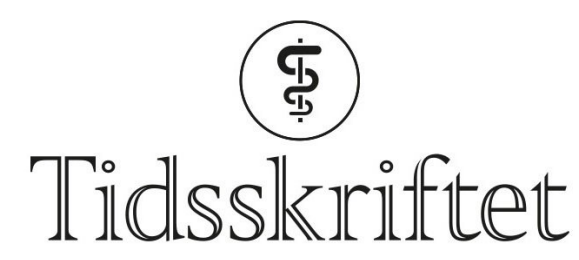

DEN NORSKE LEGEFORENING

\title{
En sånn bok
}

ANMELDELSER

CAMILLA JOHANNESSEN

Sykepleier, Overgrepsmottaket

Oslo legevakt

VIVIAN DALAKER

Lege, Overgrepsmottaket

Oslo legevakt

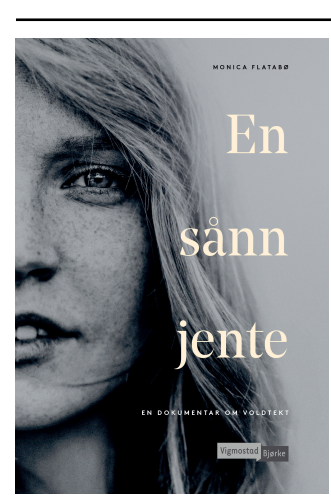

Monica Flatabø

En sånn jente

En dokumentar om voldtekt. 277 s. Bergen:Vigmostad \& Bjørke, 2017. Pris NOK 349

ISBN 978-82-419-1365-5

En sånn jente er en dokumentarbok om voldtektsutsatte. Den ble utgitt en måned før metookampanjen startet.

Som VG-journalist fulgte forfatteren rettssaken mot Julio Kopseng, mannen som ble dømt til 21 års forvaring, lovens strengeste straff, for mange voldtekter. I rettsalen fortalte 17 kvinner sin historie. En av disse vies stor plass - Marthe Stavrum var Kopsengs samboer i ni måneder.

Flatabø beskriver også møter med Andrea Voll Voldum, fra den såkalte Hemsedal-saken, og hennes foreldre.

Hun setter søkelys på jenter og ungdomsmiljø. Mange jenter vokser opp i det som beskrives som en ukultur, hvor de utsettes for overgrep/voldtekt og i etterkant stemples som horer, mens guttene får kred. At overgrep også filmes og deles, er et tilleggstraume som mange er opptatt av og bekymrer seg for. Flatabø skriver om de vanligste voldtektene i Norge - de som skjer på fest/nachspiel og der overgriperen er en man kjenner eller vet hvem er. Dette 
er et oppgjør med mytene omkring voldtekt og tabuet det er å snakke om det.

Hun beskriver godt hvordan det er for den utsatte å gå gjennom en rettssak. Lang ventetid før saken kommer opp, og så er det likevel ikke over når saken er avgjort. Jentene i boken vil ikke bli sett på som ofre. Mange har stor frykt for ikke å bli trodd - av helsevesen, venner, familie, politi og rettsvesen. Det er erfaringer vi kjenner til fra vårt arbeid på overgrepsmottak.

En sånn jente setter seksuelle holdninger på dagsordenen. Dette er viktig i en tid hvor både overgrepsmottakene og politiet ser en økning i antall unge jenter som søker hjelp etter ulike overgrep. Voldtekt er et stort helse- og samfunnsproblem. Det rammer ikke bare offeret, men også dem rundt. Som moren til Andrea sier: «Vi håper hun en dag kan bo for seg selv.»

Vi får et innblikk i normale etterreaksjoner som skyld, skam, økt beredskap, søvnvansker, spiseproblemer og seksuelle problemer.

Boken starter med et sitat: «... women get raped because someone rape them.» Ved vold i nære relasjoner er det fortsatt slik at de fleste spør hvorfor hun ikke går, istedenfor å spørre hvorfor han ikke slutter å slå.

Flere av spørsmålene som stilles på omslagssiden bak blir ikke besvart, likevel er dette en viktig bok for dem som møter overgrepsutsatte og deres pårørende. Den viser også at seksualundervisning bør komme sterkere og tidligere inn i skolen.

Publisert: 28. mai 2018. Tidsskr Nor Legeforen. DOI:10.4045/tidsskr.18.0109

(C) Tidsskrift for Den norske legeforening 2020. Lastet ned fra tidsskriftet.no 